\title{
A Case of Severe Plasmodium Vivax
Infection Complicated by ARDS and Multiple Organ Involvement
}

\author{
ARDS ve Çoklu Organ Tutulumu ile Komplike Ciddi Plasmodium Vivax \\ Enfeksiyonu Olgusu
}

Burcu Acar Çinleti' ${ }^{1}$ Bengisu Arabacı², Filiz Yıldız' ${ }^{1}$ Ozgur Samancilar², Ozlem Ediboglu' ${ }^{1}$ Cenk Kıraklı'

\begin{abstract}
Complicated malaria is caused mainly by Plasmodium falciparum, and increasingly nowadays by Plasmodium vivax. We report a case of vivax malaria complicated by acute respiratory distress syndrome and treated with extracorporeal membrane oxygenation. A 49-year-old patient was operated due to squamous cell carcinoma. After a successful right upper lobectomy operation, he became hypoxemic and developed progressive bilateral lung infiltrates. He had fever, thrombocytopenia and splenomegaly that were not present in the preoperative timeline. A peripheral blood smear verified Plasmodium vivax infection. The patient deteriorated clinically and was intubated. A bronchoscopic evaluation revealed a fistula in the lobectomy stump. Veno-venous extracorporeal membrane oxygenation was initiated due to refractory hypoxemia and to improve healing of the fistula. Our patient expired despite lung protective ventilation and extracorporeal membrane oxygenation support. This case is presented to emphasize the rare occurrence of ARDS and multiple organ failure in Plasmodium vivax infections.
\end{abstract}

Key words: Plasmodium Infections, Fever, Acute Respiratory Distress Syndrome, Extracorporeal membrane oxygenation, malaria.

\section{Özet}

Komplike malaryanın başlıca sebebi Plasmodium falciparum olmakla birlike, Plasmodium vivax sıklığı da giderek artmaktadır. Bu makalede, akut respiratuar distres sendromu ile komplike olan ve ekstrakorporeal membran oksijenasyonu desteği uyguladı̆̆ımız bir hastamızı sunduk. Hasta 49 yaşında olup, skuamöz hücreli karsinom için yapılan sağ üst lobektomi operasyonundan sonra hipoksemi gelişti ve akciğer grafisinde ilerleyici bilateral infiltratlar ortaya çıkł. Preoperatif dönemde mevcut olmayan, ateş, trombositopeni ve splenomegali görüldü. Periferik yayma yapıldı ve plasmodium vivax enfeksiyonu tespit edildi. Hipoksemisi derinleşti ve entübe edildi. Bronkoskopik değerlendirmede lobektomi güdüğünde fistül saptandı. Refrakter hipoksemi ve fistül iyileşmesi için venövenöz ekstrakorporeal membran oksijenasyonu desteğine alındı, ancak akciğer koruyucu ventilasyon stratejilerine ve ekstrakorporeal membran oksijenasyonuna rağmen hasta kaybedildi. Bu olgu ile plasmodium vivax'ın nadiren akut respiratuar distres sendromu ve çoklu organ yetmezliğine neden olabileceğini vurgulamak istedik.

Anahtar Sözcükler: Plazmodyum enfeksiyonları, ateş, akut respiratuvar distres sendromu, ekstrakorporeal membran oksijenasyonu, malarya.
'Department of Intensive Care, University of Health Sciences, Dr. Suat Seren Chest Diseases and Surgery Training and Research Hospital, İzmir, Turkey

2Department of Thoracic Surgery, University of Health Sciences, Dr. Suat Seren Chest Diseases and Surgery Training and Research Hospital, İzmir, Turkey
'Sağlık Bilimleri Üniversitesi Dr. Suat Seren Göğüs Hastalıkları ve Cerrahisi Eğitim ve Araşııma Hastanesi, Yoğun Bakım Bilim Dalı, İzmir

${ }^{2}$ Sağlık Bilimleri Üniversitesi Dr. Suat Seren Göğüs Hastalıkları Ve Cerrahisi Eğitim ve Araşıırma Hastanesi, Göğüs Cerrahisi Anabilim Dalı, İmir

Submitted (Başvuru tarihi): 27.08.2020 Accepted (Kabul tarihi): 13.12.2021

Correspondence (iletişim): Burcu Acar Çinleti, Department of Intensive Care, University of Health Sciences,

Dr. Suat Seren Chest Diseases and Surgery Training and Research Hospital, İzmir, Turkey

e-mail: burcu.cinleti@gmail.com 
Complicated or severe malaria is caused mainly by Plasmodium falciparum, and nowadays increasingly by Plasmodium vivax. The management of severe malaria may be challenging due to the complex pathophysiology of the infection and the involvement of multiple organ systems. Approximately 445,000 deaths are caused by malaria each year; among children in Africa (1).

Severe falciparum malaria is defined as having at least one of the following: impaired consciousness, prostration, multiple convulsions, acidosis, hypoglycemia, severe malarial anemia, renal impairment, jaundice, pulmonary edema, significant bleeding, shock and P. falciparum parasitemia $>10$ percent $(>500,000 / \mathrm{mcL})$. The definition of severe $P$. vivax malaria is the same, aside from their being no $P$. vivax parasite density thresholds. This case is presented to emphasize the rare occurrence of acute respiratory distress syndrome and multiple organ failure in Plasmodium vivax infection.

\section{CASE}

A 49-year-old male, ex-smoker who had previously worked in Dibouti, Africa, was diagnosed with squamous cell lung cancer, and underwent successful right upper lobectomy surgery. On the post-operative fourth day he developed a sudden high fever $\left(38.9^{\circ} \mathrm{C}\right)$ and shivering. $A$ chest $X$-ray revealed only high radiolucency at the operation site on the first days, while on the postoperative 8th day, bilateral minimal opacities were present. Since one of the early complications of lung resections are postoperative pneumonia, wide spectrum antibiotics were initiated. Daily laboratory tests revealed thrombocytopenia (platelet count $111 \times 103 \mathrm{u} / \mathrm{L}$ ), and a posteroanterior chest $X$-ray revealed new onset and rapidly progressive bilateral lung infiltrates (Figure 1). The patient developed fever accompanied by chills every three days, and the fever decreased with profound sweating, which was typical for malaria. Splenomegaly was found to be present on a physical examination. Due to traveling and working in an endemic area, malaria was considered in the differential diagnosis, even though he had been vaccinated. The patient was diagnosed with Plasmodium vivax ( $P$. vivax) infection based on a blood smear (Figure 2). After a oneweek stay in the thoracic surgery ward, the patient was moved to the chest diseases ward and was placed on artemether+lumefantrine for 3 days. The patient was accepted to our ICU due to clinical deterioration and acute hypoxemic respiratory failure. Upon admission, his body temperature was $37.1^{\circ} \mathrm{C}$, blood pressure was $120 / 80 \mathrm{mmHg}$, oxygen saturation was $92 \%$ and pulse rate was 105 bpm. A physical examination revealed bilateral respiratory crackles and splenomegaly. His hemoglobin level was $8.1 \mathrm{~g} / \mathrm{dl}$, hematocrit was 23.9, WBC count was $15.7 \times 103 / u L$ and platelet count was $76,000 / \mu \mathrm{l}$. Serum blood urea nitrogen (BUN) and creatinine levels were $37.6 \mathrm{mg} / \mathrm{dl}$ and $0.74 \mathrm{mg} / \mathrm{dl}$, respectively. The total and direct bilirubin levels were $0.95 \mathrm{mg} / \mathrm{dl}$ and $0.7 \mathrm{mg} / \mathrm{dl}$, respectively. Procalcitonin was $14.0 \mathrm{ng} / \mathrm{mL}$ and C-reactive protein was $36.9 \mathrm{mg} / \mathrm{dl}$. Aspartate aminotransferase and alanine aminotransferase were $28 \mathrm{U} / \mathrm{I}$ and $31 \mathrm{U} / \mathrm{l}$, respectively, GGT $89 \mathrm{U} / \mathrm{I}, \mathrm{LDH} 356 \mathrm{U} / \mathrm{l}$. His blood sugar and serum electrolytes were within normal ranges. His admission arterial blood gas values were as follows: $\mathrm{pH} 7.49, \mathrm{pO}_{2} 60 \mathrm{mmHg}, \mathrm{pCO}_{2} 27 \mathrm{mmHg}$, base excess $-2.2 \mathrm{mmol} / \mathrm{L}, \mathrm{HCO} 323 \mathrm{mmol} / \mathrm{L}$ and oxygen saturation $94 \%$. A chest tomography at admission to the ICU revealed bilateral patchy consolidations (Figure 3). In intensive care, we immediately drew blood, tracheal aspirate and urine cultures, and upgraded the antibiotic therapy from piperacillin/tazobactam, moxifloxacin and linezolid to colimycin, meropenem and tigecycline, and initiated noninvasive mechanical ventilation. The cultures were identified as negative. After 7 days of noninvasive ventilation (NIV), the patient's respiratory status worsened and was intubated due to NIV failure and hemodynamic instability. He was hypotensive and bolus crystalloid fluid was administered. He remained hypotensive despite fluid resuscitation, and a noradrenaline infusion was initiated.

Our patient had moderate acute respiratory distress syndrome (ARDS) according to the Berlin definition at the beginning that progressed to severe ARDS. The patient was sedated with a midazolam infusion and neuromuscular blockade was achieved with continuous infusion of rocuronium. A phentanyl infusion was initiated to prevent pain. His oxygenation gradually worsened, his $\mathrm{PaO}_{2} / \mathrm{FiO}_{2}$ ratio was 140 and he was placed in the prone position. After 20 hours of prone positioning, his $\mathrm{PaO}_{2} / \mathrm{FiO}_{2}$ ratio improved to 220 . The patient went into hemolytic crisis 8 days after admission to the ICU (10 days after the initiation of malaria treatment). The blood test values were $\mathrm{Hb}$ $6.2 \mathrm{~g} / \mathrm{dL}$, platelet count $135 \times 10^{3} / \mathrm{uL}$, potassium 7.2 mmol/L, AST 936 U/I, ALT 782 U/I, LDH 1577 U/l. He was consulted with hematology and was managed with a supportive treatment strategy. The patient suffered a generalized tonic clonic seizure and oral automatisms. An immediate computed brain tomography revealed a hemorrhagic infarct with a perilesional edema in the left cerebral cortex that was consistent with cortical venous thrombosis, and the patent was treated with low molecu- 
lar weight heparin and levetiracetam. On day 13 in the ICU, NIV was applied after an unplanned extubation (self-extubation). He remained deeply hypoxemic and his posteroanterior chest radiography revealed a right total pneumothorax. A chest tube was inserted, and a second chest tube was placed due to re-expansion failure. Even though both tubes were properly placed, the lung failed to re-expand. A bronchoscopic evaluation revealed a fistula in the lobectomy stump. A left selective bronchial intubation with a double lumen endotracheal tube was applied to bypass the fistulized area. During follow up, the patient's oxygenation and ventilation deteriorated despite $\mathrm{FiO}_{2}$ of $100 \%$, and an arterial blood gas analysis showed persistent hypoxemia $\left(\mathrm{PaO}_{2} 80 \mathrm{mmHg}\right)$ and hypercarbia $\left(\mathrm{PaCO}_{2} 129 \mathrm{mmHg}\right)$. His hypoxemia was refractory to mechanical ventilation. Since the $\mathrm{PaO}_{2} / \mathrm{FiO}_{2}$ ratio was 80 , our patient was classified with severe ARDS. His Murray score for acute lung injury was 4. Venovenous extracorporeal membrane oxygenation (ECMO) was planned to rest the lungs and to improve the healing of the bronchopleural fistula in conjunction with thoracic surgeons. Cannulas were inserted from the right internal jugular vein and right femoral vein. The cannula sights were verified via ultrasonography and chest $X$-ray, and then secured. He was subsequently initiated with a circuit flow of $4.0 \mathrm{~L} / \mathrm{min}$ and sweep gas of $5 \mathrm{~L} / \mathrm{min}$ and ECMO $\mathrm{FiO}_{2}$ of $100 \%$. All cultures were repeated, and the tracheal aspirate culture showed the growth of Stenotrophomonas maltophilia, and his antibiotics were changed following susceptibility tests. During ECMO, lung protective ventilation was continued. The mechanical ventilator adjustments were: $\mathrm{FiO}_{2} 30 \%$, PEEP $5 \mathrm{mmHg}$ and tidal volume $4 \mathrm{ml} / \mathrm{kg}$. ECMO sweep gas and circuit flow valves were adjusted according to the arterial blood gas. Pre- and post-oxygenator blood gases were controlled on a daily basis. On day 6 of ECMO, the patient's platelet levels dropped below 50,000, APTT was 48 seconds, PTZ was 15.5 seconds, INR was 1.3, and there was bleeding at the cannula site, so the heparin was discontinued. Anticoagulation with bivalirudin was planned but could not be obtained. Pooled platelets and fresh frozen plasma were transfused. ECMO membrane oxygenator failure developed on day 8 of cannulation and the cannulas were removed. No re-cannulation was made due to severe thrombocytopenia, bleeding and multi-organ failure. On day 36 in the ICU, the patient developed severe hypoxemia and hypercarbia and could not be oxygenated or ventilated. While on high dose vasopressor therapy, the patient went into cardiac arrest and as his chest wall was very rigid, chest compressions were very difficult, possibly due to phentanyl infusion. He was pronounced dead after 45 minutes of cardiopulmonary resuscitation. Despite ECMO and lung protective ventilation, the patient experienced a bad clinical course with multiple manifestations of malaria and died of septic shock and multiple organ failure.

\section{DISCUSSION}

Malaria is a major global public health problem caused by parasites that are transmitted to humans through the bites of infected female Anopheles mosquitoes. There are five parasites that cause malaria in humans, predominantly P. falciparum and P. Vivax. In 2018, the majority of malaria cases in Africa were attributed to $P$. falciparum (2). Severe malaria has such clinical manifestations as impaired consciousness, multiple convulsions, acidosis, hypoglycemia, severe anemia, renal impairment, jaundice, pulmonary edema, significant bleeding and hemodynamic instability. Severe malaria is defined as at least one of the above occurring in the absence of an identified alternative cause. Our patient had acidosis, hypoglycemia, disseminated intravascular coagulation, thrombocytopenia and pulmonary edema, had a single generalized seizure and bleeding at the puncture sites, and was in shock, and so could be defined as a severe malaria case (3). The most frequent clinical manifestations of complicated infections are cerebral malaria, renal insufficiency, metabolic acidosis and ARDS (4).

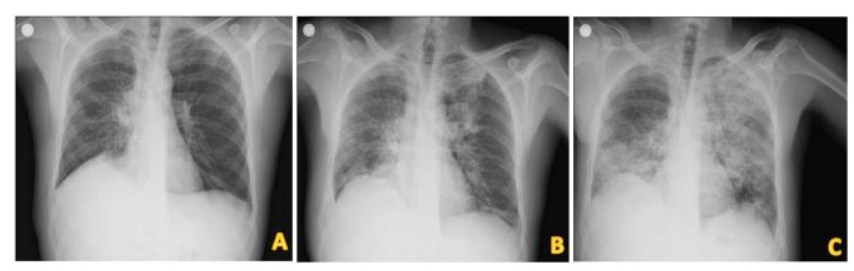

Figure 1: Progression in bilateral lung infiltrates within 3 days

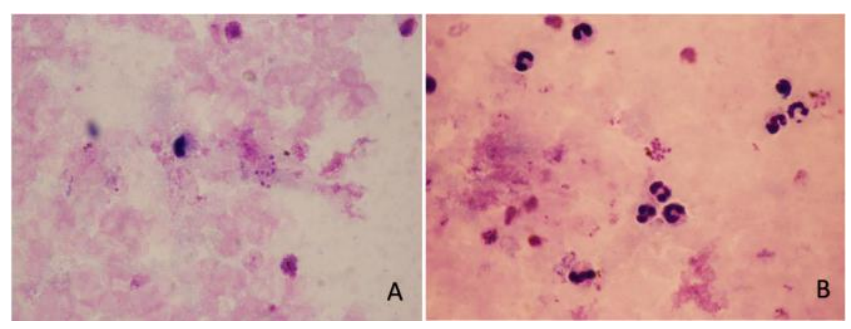

Figure 2: Plasmodium vivax in Giemsa-stained thin blood smear. A and $B$ demonstrate Plasmodium vivax schizonts in erythrocytes (Giemsa X100) 


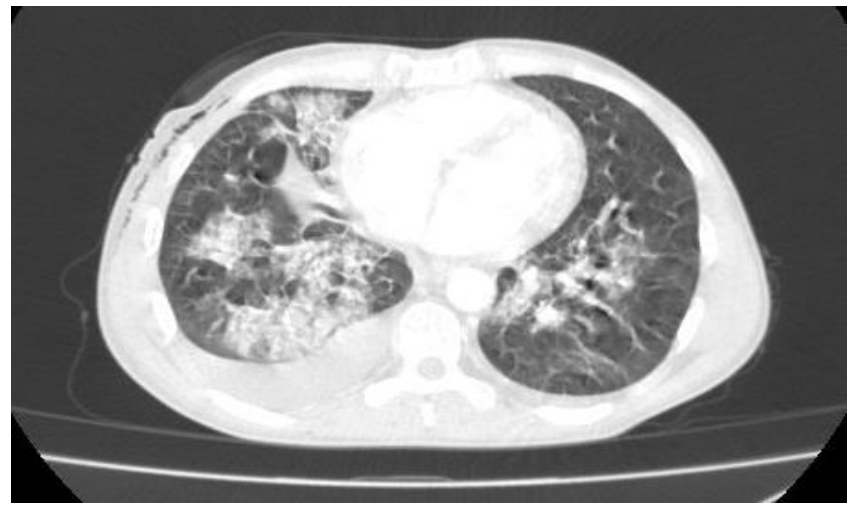

Figure 3: Bilateral patchy consolidations in ICU admission chest CT

Of the four types of malaria, $P$. falciparum malaria is the most severe as it affects multiple systems. P. vivax malaria is rarely associated with severe complications like ARDS, and was not previously believed to cause severe disease, although growing evidence indicates otherwise. A systematic review and meta-analysis revealed a prevalence of ARDS of $2.2 \%$ in adults with a mortality of $50 \%$ (5). In a case series from India, ARDS developed in 10\% of patients (6). Lung function tests on malaria patients have revealed small airway obstructions and a decrease in diffusion capacity in uncomplicated falciparum and vivax malaria. The sequestration of infected erythrocytes into the pulmonary vasculature leads to reduced diffusion capacity (7).

Severe pulmonary complications of vivax malaria are common from six hours to eight days after the initiation of anti-malarial treatment. In our patient, ARDS appeared 7 days after the start of treatment, consistent with the literature. This may be caused by the sequestration of $P$. Vivax infected erythrocytes within the pulmonary microcirculation that results in progressive alveolar-capillary dysfunction and greater inflammatory response (8). However, severe pulmonary symptoms may occur before the initiation of anti-malarial treatment. In our case, bilateral multifocal patched consolidations were reported in a thoracic computed tomography 7 days after surgery, while a chest $X$-ray on the previous day had been completely normal. Bacterial infections may play a role in the pathogenesis of ARDS in malaria, so the threshold for starting antibacterial agents should be low (9). We initiated empirical antibiotic therapy and sent the cultures for testing. The first cultures were negative, but due to clinical deterioration, we repeated the cultures and changed the antimicrobials. In a systematic review of literature into the use of noninvasive ventilation (NIV) in cases of acute lung injury (ALI)/ARDS related to $P$. vivax, NIV use in vivax malaria related ALI/ARDS was associated with a good outcome
(10). Our case underwent NIV through an oronasal mask for 7 days, but was later intubated. In ARDS patients, NIV failure was reported to occur in $22.2 \%$ of mild, $42.3 \%$ of moderate and $47.1 \%$ of patients with severe ARDS, and NIV failure was associated with higher mortality (11). Our patient had a $\mathrm{PaO}_{2} / \mathrm{FiO}_{2}$ ratio of 154 at NIV treatment, immediately prior to intubation.

The management of ARDS with invasive mechanical ventilation has its own pitfalls. It may cause barotrauma, volutrauma and biotrauma, and oxygen toxicity increases acute lung injury and inflammation (12). Extracorporeal membrane oxygenation (ECMO) is a rescue therapy that bypasses the heart and the lungs, providing gas exchange that allows ventilator settings to be reduced, giving time for treatment and recovery. It allows low-volume and lowpressure ventilation. In a case report, a 15-year-old patient who developed ARDS due to P. Vivax malaria and who underwent ECMO was weaned 90 days after the initiation of the treatment.

In our patient, ECMO membrane oxygenator failure developed on day 7 of cannulation, and the cannulas were removed. No re-cannulation was performed due to severe thrombocytopenia, bleeding, disseminated intravascular coagulation and multi-organ failure. No clots were observed in the cannulas after removal. In a case report from Korea, an ECMO cannula became blocked with clots and was removed on day 4 of treatment (13). A case of vivax malaria complicated by adult respiratory distress syndrome was successful managed with extracorporeal membrane oxygenation. ECMO can be a bridge to recovery in severe ARDS in tropical diseases such as malaria, but is a high-risk therapy that is associated with many potential complications, and should only be considered in specialized and experienced ECMO centers (14). ECMO can be considered as a rescue therapy in severe dengue, malaria and acute Chagas disease, either as a bridge to recovery or to transplantation. However, ECMO remains a high-risk therapy that should only be considered in specialized ECMO centers.

It should be emphasized that procalcitonin (PCT) is a useful marker for the assessment of disease severity in malaria. Our patient presented with Multiple Organ Failure (MOF) with cardiac, hepatic and renal compromise. In another study, all of the patients with complicated malaria had high procalcitonin levels and PCT was correlated with parasitemia (especially PCT levels above 5 $\mathrm{ng} / \mathrm{mL}$ ) (15), while a further study reported high PCT and persistent PCT elevation to be related to increased mortality (16). Our patient had a PCT level of $14 \mathrm{ng} / \mathrm{mL}$, and 
had severe malaria and a bad clinical course, similar to the previously mentioned studies.

Our patient died on day 6 of ECMO treatment and on day 36 in the ICU, despite lung protective ventilation and extracorporeal membrane oxygenation support. Inpatients with vivax malaria have a mortality of $28.2 \%$ (17). Vivax malaria is a life-threatening infection, despite the relatively low-grade parasitemia in peripheral blood. In a study from India, pulmonary involvement was seen in $1.6 \%$ of cases, and mortality associated with severe P. Vivax infection was $9 \%$, increasing with age (18).

\section{CONFLICTS OF INTEREST}

None declared.

\section{AUTHOR CONTRIBUTIONS}

Concept - B.A.Ç., B.A., F.Y., O.S., O.E., C.K.; Planning and Design - B.A.C.., B.A., F.Y., O.S., O.E., C.K.; Supervision - B.A.Ç., B.A., F.Y., O.S., O.E., C.K.; Funding -; Materials -; Data Collection and/or Processing - F.Y., B.A.; Analysis and/or Interpretation - B.A.Ç.; Literature Review - B.A.Ç., F.Y., B.A.; Writing - B.A.Ç., B.A.; Critical Review - O.S., O.E., C.K.

\section{YAZAR KATKILARI}

Fikir - B.A.Ç., B.A., F.Y., O.S., O.E., C.K.; Tasarım ve Dizayn - B.A.Ç., B.A., F.Y., O.S., O.E., C.K.; Denetleme - B.A.Ç., B.A., F.Y., O.S., O.E., C.K.; Kaynaklar -; Malzemeler -; Veri Toplama ve/veya İşleme - F.Y., B.A.; Analiz ve/veya Yorum - B.A.Ç.; Literatür Taraması - B.A.Ç., F.Y., B.A.; Yazıyı Yazan - B.A.Ç., B.A.; Eleştirel Inceleme O.S., O.E., C.K.

\section{REFERENCES}

1. World Health Organization World Malaria Report 2017. http://apps.who.int/iris/bitstream/handle/10665/25949 2/9789241565523-

eng.pdf; ;sessionid =7CE964134B0D083EA92FBB9F1F9 D4775? sequence $=1$.

2. WHO, 2016. World Malaria Report 2016.

3. Hwang J, Cullen KA, Kachur SP, Arguin PM, Baird JK. Severe morbidity and mortality risk from malaria in the United States, 1985-2011. Open Forum Infect Dis 2014; $1:$ ofu034. [CrossRef]

4. Organization WH (2015) Guidelines for the treatment of malaria, World Health Organization. Geneva, Switzerland: 9-12.
5. Val F, Machado K, Barbosa L, Salinas JL, Siqueira AM, Costa Alecrim MG, et al. Respiratory complications of Plasmodium vivax malaria: systematic review and metaanalysis. Am J Trop Med Hyg 2017; 97:733-43. [CrossRef]

6. Kochar DK, Das A, Kochar SK, Saxena V, Sirohi P, Garg $S$, et al. Severe Plasmodium vivax malaria: a report on serial cases from Bikaner in northwestern India. Am J Trop Med Hyg 2009; 80:194-8. [CrossRef]

7. Taylor WRJ, Hanson J, Turner GDH, White NJ, Dondorp AM. Respiratory manifestations of malaria. Chest 2012; 142:492-505. [CrossRef]

8. Anstey NM, Handojo T, Pain MC, Kenangalem E, Tiitra E, Price $\mathrm{RN}$, et al. Lung injury in vivax malaria: pathophysiological evidence for pulmonary vascular sequestration and posttreatment alveolar-capillary inflammation. J Infect Dis 2007; 195:589-96. [CrossRef]

9. Karnad DR, Nor MBM, Richards GA, Baker T, Amin P; Council of the World Federation of Societies of Intensive and Critical Care Medicine. Intensive care in severe malaria: Report from the task force on tropical diseases by the World Federation of Societies of Intensive and Critical Care Medicine. J Crit Care 2018; 43: 356-60. [CrossRef]

10. Agarwal R, Nath A, Gupta D. Noninvasive ventilation in Plasmodium vivax related ALI/ARDS. Intern Med. 2007; 46:2007-11. [CrossRef]

11. Bellani G, Laffey JG, Pham T, Madotto F, Fan E, Brochard $L$, et al. Noninvasive ventilation of patients with acute respiratory distress syndrome. Insights from the LUNG SAFE Study. Am J Respir Crit Care Med 2017; 195:67-77. [CrossRef]

12. Peek GJ, Mugford M, Tiruvoipati R, Wilson A, Allen E, Thalanany MM, et al. Efficacy and economic assessment of conventional ventilatory support versus extracorporeal membrane oxygenation for severe adult respiratory failure (CESAR): a multicentre randomised controlled trial. Lancet 2009; 374:1351-63. [CrossRef]

13. Lee HJ, Baek JH, Chae MH, Joo H, Lee JS, Chung MH, et al. A case of vivax malaria complicated by adult respiratory distress syndrome and successful management with extracorporeal membrane oxygenation. Korean J Parasitol 2013; 51:551-5. [CrossRef]

14. Salazar LA, Schreuder CM, Eslava JA, Murcia AS, Forero MJ, Orozco-Levi MA, et al. Extracorporeal membrane oxygenation in Dengue, Malaria, and acute Chagas disease. ASAIO J 2017; 63: e71-e76. [CrossRef]

15. Righi E, Merelli M, Arzese A, Siega PD, Scarparo C, Bassetti $M$. Determination of PCT on admission is a useful tool for the assessment of disease severity in travelers with 
imported Plasmodium falciparum malaria. Acta Parasitol 2016; 61:412-8. [CrossRef]

16. Chiwakata CB, Manegold C, Bönicke L, Waase I, Jülch C, Dietrich M. Procalcitonin as a parameter of disease severity and risk of mortality in patients with Plasmodium falciparum malaria. J Infect Dis 2001; 183:1161-4. [CrossRef]
17. Rahimi BA, Thakkinstian A, White NJ, Sirivichayakul C, Dondorp AM, Chokejindachai W. Severe vivax malaria: a systematic review and meta-analysis of clinical studies since 1900. Malar J 2014; 13:481. [CrossRef]

18. Nadkar MY, Huchche AM, Singh R, Pazare AR. Clinical profile of severe Plasmodium vivax malaria in a tertiary care centre in Mumbai from June 2010-January 2011. J Assoc Physicians India 2012; 60: 11-3. 